\title{
EVALUATION OF INTRAVENOUS IRON THERAPY RESPONSE TO MANAGE ANEMIA IN PREGNANCY
}

\author{
SAHA $\mathrm{J}^{1}$, QUADER MA ${ }^{2}$, ISLAM $\mathrm{F}^{3}$, PRASAD I ${ }^{4}$, KHANOM KA ${ }^{5}$, SIDDIQUE $\mathrm{S}^{6}$, AKKER $\mathrm{S}^{7}$, \\ TALUKDER DC ${ }^{8}$, SAHA $\mathrm{H}^{9}$, SHAMNAZ $\mathrm{T}^{10}$
}

\begin{abstract}
:
Background: Iron deficiency anaemia is a common problem in antenatal patient especially in primigravida in developing world. The study was conducted to evaluate the efficacy of intravenous iron sucrose in antenatal primigravida anaemic cases.

Aims and Objectives: The study was conducted to evaluate the response of intravenous iron therapy in anaemic antenatal primigravida patients. The rise of hemoglobin level was predicted after therapy.

Materials and Methods: A prospective cross-sectional study was done in the antenatal clinic of Popular Medical College Hospital from January 2016 to December 2016. Primigravida women of $e^{\prime \prime} 18$ years with iron deficiency anaemia were included in this study. Pretreatment hemoglobin level was measured. After total dose of calculated iron, intravenous iron sucrose was infused to achieve the target hemoglobin. After completion of therapy hemoglobin was measured 2 weeks and 4 weeks after last dose of iron treatment. Mean, percentage, Chi-square test was done and $P$ value $<0.05$ was considered significant.

Results: Among the 63 primigravida anaemic patients mean age of the study subjects were 23.98 years with mean gestational age were 23.54 weeks. Their pretreatment hemoglobin level was $5.42 \mathrm{gm} / \mathrm{dl}$. After total dose infusion of iron sucrose, the mean rise of hemoglobin after 2 weeks was $8.87 \mathrm{gm} / \mathrm{dl}$ and after 4 weeks was $10.87 \mathrm{gm} / \mathrm{dl}$ respectively. This findings were statistically significant $(P<0.001)$. Attainment of target hemoglobin at the range of $9.1-11.0 \mathrm{gm} /$ dl was $50.79 \%$ and $65.08 \%$ after 2 weeks and 4 weeks respectively.
\end{abstract}

Conclusion: Parenteral iron therapy in the form of iron sucrose proved to be better choice to correct iron deficiency anaemia in primigravida anaemic patients.

Key words: Intravenous iron, anaemia, primigravida.

J Dhaka Med Coll. 2018; 27(1) : 79-82

\section{Introduction:}

In underdeveloped countries, anaemia is a major contributory factor to maternal morbidity. ${ }^{1}$ According to WHO about 50 percent of women of fertile age have iron deficiency anaemia. ${ }^{2}$ According to $\mathrm{WHO}^{3}$ anaemia is defined as "hemoglobin less than $11 \mathrm{gm} / \mathrm{dl}$ and a hematocrit of less than 0.33". Most women begin their pregnancy with partially or completely depleted of iron reserves. Thus the severity of the anaemia is inversely related to the amount of iron reserves. ${ }^{4}$
Anaemia has an estimated global prevalence of $42 \%$ average pregnant women. It is estimated that anaemia causes more than 115000 maternal and 591000 perinatal death globally per year. ${ }^{5}$ The base line measure of hemoglobin concentration that categorizes anaemia is less than 7.0gm/dl severe anaemia ,7.0-9.9 gm/dl moderate and $10.0-11.9 \mathrm{gm} / \mathrm{dl}$ for mild anaemia. ${ }^{6}$

Various studies have assessed the association between severe anaemia and maternal mortality. Brabin et. al. in a review used cross-

1. Dr. Joysree Saha. Assistant Professor, Dept. of Gyane and Obs, Popular Medical College

2. Dr. Md. Abdul Quader, Assistant Professor, Dept. of Transfusion Medicine, Popular Medical College

3. Prof. Ferdousi Islam, Professor, Dept. of Gyane and Obs, Popular Medical College.

4. Dr. Indrajit Prasad, Associate Professor, Dept. of Endocrinology, Dhaka Medical College

5. Dr. Kamil Ara Khanom, Associate professor, Dept. of Gyane and Obs, Popular Medical College

6. Dr. Sohana Siddique, Associate professor \& Head, Dept. of Gynae \& Obs , International Medical college hospital

7. Dr. Sumaya Akter, Registrar, Dept. of Gyane and Obs, Popular Medical College

8. Dr. Debesh Chandra Talukder, Associate Professor, Department of ENT, Dhaka Medical College

9. Dr. Haridas Saha, Assistant Professor, Department of Surgery, Dhaka Medical College

10. Dr. Tasrina Shamnaz, Assistant Professor, Department of Medicine, Delta Medical College, Dhaka

Correspondence: Dr. Joysree Saha, Assistant Professor, Dept. of Gyane and Obs. Popular Medical College, Cell 01765579727, E-mail: sahajoysree1@yahoo.com

Received: 21 July $2017 \quad$ Revision: 18 August 2017

DOI: http://dx.doi.org/10.3329/jdmc.v27i1.38951

Accepted: 01 September 2017 
sectional, longitudinal and case-control studies and found a strong association between severe anaemia and maternal mortality. However, the association was not as strong for mild or moderate anaemia. ${ }^{7}$ Harrison found that both maternal and fetal mortality rises sharply in cases of severe anaemia. The causes of maternal death were due to anaemic heart failure, fulminating bacterial infection and shock from even a small loss of blood at delivery or abortion. [8] Severe anaemia was associated with a four folds increase in risk of death in a study by Fullerson and Turner. ${ }^{9}$

Women often become anaemic during pregnancy because of increase in demand for iron and other vitamins in the body. It is estimated that the blood volume increased approximately 50 percent during pregnancy, although the plasma amount is disproportionately greater. This causes dilution of the blood, making the hemoglobin concentration fall, with hemoglobin concentration of its lowest between weeks 25 and 30. Iron deficiency anaemia is a major health problem worldwide, but responds well to iron supplementation. New approaches are leading to more effective management of this condition. Patients are commonly prescribed oral iron preparation because of convenience and low cost. However, the efficiency of these agents is limited by their reduced absorption rate and gastrointestinal side effects and compliance.

We therefore evaluated the efficiency and safety of intravenous iron sucrose for the treatment of iron deficiency anaemia in pregnant women.

\section{Materials and Methods:}

This was a perspective cross sectional study carried out in the Gynaecology outpatient department (GOPD) of Popular Medical College Hospital during the period of January 2016 to December 2016. After ethical clearance, the antenatal women attending the GOPD and antenatal clinic were included in the study with following inclusion and exclusion criteria.

\section{Inclusion criteria:}

1. Pregnant women aged e" 18 years

2. Gestational age between 16 to 32 weeks
3. Willing to give confirm consent form for the study

4. IDA (iron deficiency anaemia) defined as $\mathrm{Hb}$ concentration $<8 \mathrm{gm} / \mathrm{dl}$

5. All primigravida females of above criteria

\section{Exclusion criteria:}

1. Gestational age $<16$ or $>32$ weeks

2. Having $\mathrm{Hb}$ concentration $>8 \mathrm{gm} / \mathrm{dl}$

3. $\mathrm{H} / \mathrm{O}$ allergic reactions to previous iron therapy

4. Anaemia due to causes other than iron deficiency

5. Other inter current diseases

6. Other iron supplementation taken previously (oral iron, packed RBC, blood transfusion)

All the women who met the inclusion criteria was given intravenous a total dose of iron sucrose. Iron sucrose was given by intravenous injection on alternate day according to the iron deficit calculated for each individual patient. $200 \mathrm{gm}$ elemental iron diluted in $100 \mathrm{ml}$ of $0.9 \%$ normal saline infusion over 30 minutes upto the total calculated dose.

Total iron required $=$ Body weight $(\mathrm{kg}) \mathrm{x}$ [targeted $\mathrm{Hb}(\mathrm{gm} / \mathrm{dl})$ - Actual Hb (gm/dl) x 0.24 + 500mg. The targeted $\mathrm{Hb}$ was taken as $12 \mathrm{gm} / \mathrm{dl}$ because of physiological Hemoglobin during pregnancy. Actual Hemoglobin was the $\mathrm{Hb}$ at the time of infusion. 0.24 was the correction factor and 500 gm was average stored iron in adults. Treatment was stopped either after administration of the calculated dose or once the Hemoglobin level had reached $10 \mathrm{gm} / \mathrm{dl}$. Hemoglobin level was measured 2 weeks and 4 weeks after the last dose of intravenous iron therapy.

\section{Statistical Analysis:}

Descriptive statistics in the form of mean and standard deviation for interval variables and frequency and percentage for categorical variables were calculated. $P$ value less than 0.05 has been considered statistical significance level. SPSS version 16.0 was used for the analysis.

\section{Results:}

On inclusion, all the primigravida patients of gestational age between 16 to 32 weeks were 
documented and pretreatment or baseline hemoglobin level was measured. Table-1 showed the age distribution of study subjects with age range of 19 to 36 years and the mean age was 25.98 years. The mean gestational age of the study subjects were 23.54 weeks (Table-2). Pretreatment or baseline hemoglobin level of the subjects showed 12 (19.05\%) had d" $4.0 \mathrm{gm} / \mathrm{dl}$. Most of the cases had their hemoglobin level between 4.1-6.0 $\mathrm{gm} / \mathrm{dl}$ ( $\mathrm{n}=33,52.38 \%)$. Remaining 18 (28.57\%) had hemoglobin level 6.1-8.0 gm/dl (Table3). Table-4 showed the hemoglobin level after total dose of infusion of iron sucrose after 2 weeks and 4 weeks. After 2 weeks of treatment completion maximum 32(50.79\%) showed hemoglobin level attainment in range of 9.1$11.0 \mathrm{gm} / \mathrm{dl}$. After 4 weeks, $41(65.08 \%)$ showed attainment of hemoglobin level of 9.1-11.0 $\mathrm{gm} / \mathrm{dl}$ range. The mean increment of hemoglobin after 2 weeks and after 4 weeks was $8.87 \mathrm{gm} / \mathrm{dl}$ and $10.07 \mathrm{gm} / \mathrm{dl}$ respectively. This finding is statistically significant. ( $\mathrm{P}<0.001)$.

Table-I

Age distribution of study subjects.

\begin{tabular}{lcc}
\hline Age & Number & Percentage \\
\hline 19-24 years & 28 & $44.44 \%$ \\
25-30 years & 23 & $36.51 \%$ \\
31-36 years & 12 & $19.05 \%$ \\
\hline Total & 63 & $100.00 \%$ \\
\hline
\end{tabular}

Mean age- 25.98 years

Table -II

Distribution of subjects according to gestational age.

\begin{tabular}{lcc}
\hline Gestational age & Number & Percentage \\
\hline 16-20 weeks & 13 & $20.63 \%$ \\
21-24 weeks & 27 & $42.86 \%$ \\
25-28 weeks & 15 & $23.81 \%$ \\
29-32 weeks & 8 & $17.70 \%$ \\
\hline Total & 63 & $100.00 \%$ \\
\hline
\end{tabular}

Mean $=23.54$ week
Table-III

Hemoglobin level of study subjects before treatment

\begin{tabular}{lcc}
\hline Hb level & Number & Percentage \\
\hline$\leq 4.0 \mathrm{gm} / \mathrm{dl}$ & 12 & $19.05 \%$ \\
$4.1-6.0 \mathrm{gm} / \mathrm{dl}$ & 33 & $52.38 \%$ \\
$6.1-8.0 \mathrm{gm} / \mathrm{dl}$ & 18 & $28.57 \%$ \\
Total & 63 & $100.00 \%$ \\
\hline
\end{tabular}

Mean $\mathrm{Hb}$ level $5.42 \mathrm{gm} / \mathrm{dl}$

Table-IV

Hemoglobin level 2 weeks and 4 weeks after completion of therapy.

\begin{tabular}{|c|c|c|c|c|}
\hline $\mathrm{Hb}$ level & \multicolumn{2}{|c|}{ After 2 weeks } & \multicolumn{2}{|c|}{ After 4 weeks } \\
\hline (gm/dl) & Number & Percentage & Number & Percentage \\
\hline $5.1-7.0$ & 9 & $14.29 \%$ & - & - \\
\hline $7.1-9.0$ & 20 & $31.75 \%$ & 7 & $11.11 \%$ \\
\hline $9.1-11.0$ & 32 & $50.79 \%$ & 41 & $65.08 \%$ \\
\hline$\geq 11.1$ & 2 & $3.17 \%$ & 15 & $23.81 \%$ \\
\hline Total & 63 & $100.00 \%$ & 65 & $100.00 \%$ \\
\hline Mean & \multicolumn{2}{|c|}{$8.87 \mathrm{gm} / \mathrm{dl}$} & \multicolumn{2}{|c|}{$10.07 \mathrm{gm} / \mathrm{dl}$} \\
\hline
\end{tabular}

$\chi^{2}=26.3, \mathrm{df}=3, \mathrm{P}<0.001$

\section{Discussion:}

Iron deficiency anemia is a major health problem worldwide but responds well to iron supplementation. Iron deficiency anemia during pregnancy is common and deserves special attention because of its potential consequences. The current study was undertaken to evaluate the efficiency of intravenous iron sucrose therapy for treating anemia during pregnancy.

The mean hemoglobin of the study subjects were $5.42 \mathrm{gm} / \mathrm{dl}$ at booking time. After completion of total iron dose of iron sucrose therapy the mean rise was $8.87 \mathrm{gm} / \mathrm{dl}$ after 2 weeks and $10.07 \mathrm{gm} / \mathrm{dl}$ after 4 weeks. The rise was 3.4 $\mathrm{gm} / \mathrm{dl}$ after 2 weeks and $4.65 \mathrm{gm} / \mathrm{dl}$ after 4 weeks. The rise in hemoglobin level was $2.6 \mathrm{gm} /$ dl showed by Hashemi et. al. ${ }^{10}$ and $2.8 \mathrm{gm} / \mathrm{dl}$ by Waili et. al. ${ }^{11}$ after 3 weeks of intravenous iron sucrose therapy was similar to the present study.

Study done by Lomte DB et. al. ${ }^{12}$ showed mean age of the subjects were 36.46 years with mean 
gestational age was 24.48 weeks which was similar to the present study. They also showed that the mean pretreatment hemoglobin was $6.49 \mathrm{gm} / \mathrm{dl}$ and after therapy the hemoglobin rise was $2.33 \mathrm{gm} / \mathrm{dl}$ after 2 weeks and $3.52 \mathrm{gm} /$ dl after 4 weeks of treatment completion. The present study also showed similar rise of hemoglobin after 2 weeks and 4 weeks of treatment completion.

In the present study we gave iron sucrose in primigravida anemic patients. There was significant rise if hemoglobin after 2 weeks and 4 weeks of completion of total dose iron therapy. This was statistically significant $(\mathrm{P}<0.001)$. Highly significant rise of hemoglobin concentration was also reported by Francoise B et. al. ${ }^{13}$

The present study showed that targeted hemoglobin concentration was achieved $53.96 \%$ after 2 weeks of therapy and $88.89 \%$ after 4 weeks of therapy. Similar finding was showed by Lomte DB et. al. ${ }^{13}$ and Hashemi $Z$ et.al. [10] study. The increment was statistically significant. The result of our study showed that the mean hemoglobin level achieved was significantly higher and achievement of targeted hemoglobin also higher. So the intravenous iron sucrose therapy could be a modality of treatment in anemia in pregnancy specifically in primigravida.

\section{Conluction}

Parenteral iron therapy in the form of iron sucrose proved better choice to correct iron deficiency anemia in pregnancy. If given in time, this will help to reduce the risk of blood transfusion during the peripartum period.

\section{Conflict of Interest: None}

\section{Acknowledgement:}

Authors showed their acknowledgement for all the participating primigravida patients who consented to fulfillment of this research work. Also showed gratitude to the laboratory personnel's who did their endeavor to correct measurement of hemoglobin level.

\section{References:}

1. Perewusuy KG, Huck R, Huck A, Breymann C. Parenteral iron-sucrose complex. Br J Nutr 2002;88:3-10.
2. Nisar N, white F. Factors affecting utilization of antenatal care among reproductive age group women (15-49 years) in an urban squatter settlement of Karachi. J Pak Med Assoc 2003;53:47-53.

3. Breymann C. Iron deficiency and anemia in pregnancy: Modern aspects of diagnosis and therapy. Blood cells Mol Dis 2002;29:506-16.

4. Khan MM. Effects of maternal anemia on fetal parameters. J Ayub Med Coll Abbottabad 2001;13:38-41.

5. Y. Balaranjan, V. Ramakrishnan, E. özaltin, A. H. Shankar and S. V. Subramanian. "Anemia in low income and middle income countries." Lancet 2011;378(9809):2123-2135.

6. E. M. Demaeyer, P. Dallman, J. M. Gurney, L. Hallberg, S.K. Sood and Srikanta. "Preventing and controlling iron deficiency anemia through primary healthcare: a guide for health administrators and programme managers." World Health Organization, Geneva, Switzerland 1989.

7. B. J. Brabin, M. Hakimi, D. Pelletier. "Iron deficiency anemia: reexamining the nature and magnitude of public health problem." Journal of Nutrition 2001;131:6045-6155.

8. K. A. Harrison. "Blood transfusion in severe anemia in pregnancy." In: Proceeding of the international seminar on Maternal Mortality, Family Planning and Biology of Reproduction. B. N. Purandare and C. L. Jhaveri eds. pp-67-70. Federation of obstetric and gynaecological society of India, Bombay, India, March 1969.

9. W. T. Fullerton, A. G. Turner. Exchange transfusion in the treatment of severe anemia in pregnancy. The Lancet 1962;279(7220):75-78.

10. Hashimi Z, Bushir G, Azzem P. Effectiveness of intravenous iron sucrose complex versus intramuscular iron sorbitol in iron deficiency anemia. Ann Pak Inst. Med Sci 2006;2:188-91.

11. Waili A, Mushtaq A. Comparative study- efficacy, safety and compliance of intravenous iron sucrose and intramuscular iron sorbitol in iron deficiency anemia of pregnancy. J Pak Med Assoc.2002;53:39295.

12. Lomte DB, Bhosale RS, Jambdade V, Gore PR. Comparative study on efficacy and safety of intravenous iron sucrose versus intramuscular iron sorbitol therapy in anemia during pregnancy. Int Med Res Health Sei 2013; 2(4):719-723.

13. Francoise B, Carole SB, Nour-Eddine B, Henryse L, Particia MB, Marie CL. Iron therapy in iron deficiency anemia in pregnancy: Intravenous route versus oral route. Ann J Obstet Gynacol 2002;186:518-22. 